\title{
Volyn and the Unperceived Ukrainian in the work of Włodzimierz Odojewski.
}

\section{Uilleam Blacker}

The Polish Review, Vol. 64, No. 2, Collective Suffering in the Polish Lands (2019), pp. 94103.

Of all of the post-World War II 'kresy’ writers, Włodzimierz Odojewski represents the most prominent inheritor of the $19^{\text {th }}$ century Romantic tradition of writing about Ukraine as a wild land of adventure and danger filled with unruly natives. ${ }^{1}$ Indeed, Maria Janion called his most famous novel, Zasypie wszystko, zawieje... (Everything will be covered by snow, 1973), 'the most Romantic novel of 20th century Polish literature'. ${ }^{2}$ This sense of a continuity of tradition was, undoubtedly, alongside the fact that the novel was written at a time when the topic was still taboo in socialist Poland, ${ }^{3}$ one of the factors that allowed it to so powerfully influence Poles' memory of one of the most traumatic pages of their mid- $20^{\text {th }}$ century: the Volyn massacres, in which thousands of Polish civilians in the former eastern borderlands were murdered by their Ukrainian neighbours and Ukrainian nationalist forces. The crucial role of Zasypie wszystko, zawieje... in shaping the image of the Volyn massacres for Polish society is such that the major Polish newspaper Rzeczpospolita named Zasypie wszystko, zawieje... 'the best thing ever written about Volyn'. ${ }^{4}$ Zasypie wszystko, zawieje..., the novel Wyspa ocalenia (Island of Salvation, 1966) and the earlier collection of stories, Zmierzch

\footnotetext{
${ }^{1}$ On post-war 'kresy' writing, see Jerzy Jarzębski, 'Exodus (ewolucja obrazu kresów po wojnie)' in W Polsce czyli wszędzie (Warsaw: PEN, 1992), pp. 129-147; Dorota Sapa, Między polska wyspa a ukraińskim morzem: kresy południowo-wschodnie w polskiej prozie 1918-1988 (Kraków: Universitas, 1998); Eugeniusz Czaplejewicz and Edward Kasperski Literatura i różnorodność. Kresy i pogranicza (Warsaw: DiG, 1996). On Odojewski specifically, see Maria Janion, 'Cierń i róża Ukrainy’, in Wobec zła (Chomotów: Verba, 1989), pp. 173-209. On Ukraine as Romantic chronotope see Danuta Sosnowska, 'Przesłanie Wernyhory. O romantycznej fascynacji Ukrainą', Przegląd wschodni, 1991, 1, 4, 737-753 (p. 738).

2 Janion, 'Cierń i róża Ukrainy', p. 185.

${ }^{3}$ Vlodizmiezh Odoievs'kyi (Włodzimierz Odojewski), 'Polsko-ukrains'ka tematyka v suchasnii pol'skii prozi', Vidnova, 3, 1985, 63-78 (p. 71)

${ }^{4}$ Marcin Kube, 'Książki przybliżają prawdę o Wołyniu', Rzeczpospolita, 18 October 2016, https://www.rp.pl/Literatura/310189909-Ksiazki-przyblizaja-prawde-o-Wolyniu.html
} 
świata (Twilight of a world, 1962) follow the fates of two cousins, Paweł Woynowicz and Piotr Czerestwieński, and their families, and constitute what is known as the 'cykl podolski', or Podolian cycle, in Odojewski's work. ${ }^{5}$ The Woynowiczs have lived in the region of Podillia (Podole in Polish) for generations. Paweł's elder brother Aleksy is killed at Katyn, leaving Paweł as the head of the household, committed to defending his home and the Polish presence in the area. The Czerestwieńskis are relative newcomers: Piotr's grandfather, a Russian who married into a Polish family, bought his estate after fleeing the Bolshevik revolution. Piotr has spent much of his youth away from the region and his feelings about it are based in childhood memories rather than patriotism. This changes when he discovers that he has an illegitimate half-brother, Semen Gawryluk, the son of his father and a Ukrainian peasant woman, who is now the leader of a gang of Ukrainian nationalists that has targeted his family. Piotr joins the fight against the Ukrainian nationalists and swears to kill his halfbrother. The final central character is Katarzyna, Aleksy's young widow, who was adopted and brought up by the Czerestwieńskis. Katarzyna has a romance with Piotr, but is also the object of Paweł's feelings, causing tension between the cousins.

Odojewski's depiction of the Polish-Ukrainian conflict through this family saga has divided critics. One early reviewer saw genuine efforts to understand the events of 1943-44: $[\ldots]$ this is a book also about hatred, its reasons and its horrific effects. But it is also a book that tries to understand hatred and to bridge the gulf that hatred can create between peoples occupying the same land. ${ }^{6}$

\footnotetext{
${ }^{5}$ Odojewski also treats Ukrainian-Polish relations in works written both before and after the Podolian trilogy, most notably his early, ideologically-tinged Opowieści leskie (Forest stories, 1954) and his later story 'Jedźmy, wracajmy...' (Let's go, let's return, 1993) and novel Oksana (1999). For reasons of space, I will focus only on the works in the Podolian trilogy.

${ }^{6}$ Alina Jasińska, 'Zasypie wszystko, zawieje... Wielkie obsesje Włodzimierza Odojewskiego' in Stanisław Barć (ed.), Odojewski i krytycy. Antologia tekstów (Lublin: Wydawnictwo Uniwersytetu im. Marii Curie Skłodowskiej, 1999), pp. 124-126 (the review was first published in the London émigré newspaper Tydzień Polski in 1974).
} 
Maria Janion insists that the Ukraine of the novels is 'very real [...] particularly in the image of the murderous conflict between two nations doomed to constantly fight one another' ${ }^{7}$ while Sławomir Mazurek states that 'Odojewski’s novel, more bravely than any other text that I know, illustrates the similarities between the experiences of both nations' ${ }^{8}$

There are certainly moments in Odojewski's trilogy when the reader is encouraged to consider the historical, political, cultural and social realities of the conflict. Zasypie wszystko, zawieje... features a passage where Piotr's uncle Teodor, a widely-travelled cosmopolitan, speaks to Paweł about the problem. First, he considers nationalities and ethnicity, pointing out that while this seems to divide the Woynowicz's from the peasantry, in reality Pawel's ancestors probably came from the autochthonous population and assimilated into Polish culture: they are 'authentic sons of this land. So why the hatred?' ${ }^{9}$ He then turns to language, pointing out that there are native Polish speakers fighting with Gawryluk, and Ukrainian speakers in the Polish partisans. He then considers class, recounting a scene he once witnessed of a pregnant peasant woman being whipped for falling behind with her work:

When they come to rob your houses, when before that they destroyed the Jewish shops, inns and markets in the small towns, when they destroy the churches and hang the priests, I always hear it [the sound of the whip]. It's shameful, what they are doing, but generations of working them to the bone must have given rise to the desire to possess what you have. ${ }^{10}$

He then counters this with examples of well-off peasants fighting with the nationalists and poorer ones fighting against them. Eventually, he concludes:

\footnotetext{
${ }^{7}$ Janion, 'Cierń i róża Ukrainy’, p. 183. Here, Janion is countering arguments made by Jerzy Krzyżanowski in his comparison of Odojewski with Faulkner. See Krzyżanowski, 'The land of no salvation', Polish Review 23, $2,1978,17-30$

${ }^{8}$ Sławomir Mazurek, 'Zmierzch koliszczyzny (Polska i Ukraina w Zasypie wszystko, zawieje... Włodzimierza Odojewskiego)’, in Stanisław Barć (ed.), Odojewski i krytycy. Antologia tekstow (Lublin: Wydawnictwo Uniwersytetu im. Marii Curie Skłodowskiej, 1999), pp. 127-134.

${ }^{9}$ Włodzimierz Odojewski, Zasypie wszystko, zawieje... (Paris: Instytut Literacki, 1973), p. 198.

${ }^{10}$ Odojewski, Zasypie wszystko, zawieje... p. 199.
} 
Maybe the reason for all this is elsewhere? Maybe, like a mosaic, it's made of many elements that I just can't put together? I keep thinking about it and I can't understand it. I only know that I don't want anything to do with it, though it can draw you in like a whirlpool. Darkness, primitiveness, barbarity. ${ }^{11}$

In Zasypie wszystko, zawieje..., meanwhile, as he travels through the war-torn landscape and considers the same problems, Pawel abandons rational explanations and reverts to viewing the violence as incomprehensible and inescapable. For him, the 'cycle of violence' seems to emanate from the land itself, and is ultimately a question of fate:

In the endless, empty wilderness there was something unforgivingly severe, merciless and hungry for death. [...] He thought of all the villages that had once been here, inhabited by farm workers, Ukrainians or Ruthenianized settlers from other parts of the Republic, who for many years had been incited to ill-fated rebellions, first by the Soviets, then the Germans, and then by their own leaders, the noble national desires of this people now drowning in murder and rape, robbery and fire, shaming them forever. He thought of how this primitive element, awakened from its lair first by deceptive slogans about class, then about nations and races, in which one thing was common - hatred - had spread around the region. [...] 'Mob [czerń]!' he whispered. ${ }^{12}$ Paweł also, in the same passage, reflects on 'his own people', who are 'unable to build anything good without first arguing about it, without throwing themselves at each other with their fists and falling into a sea of blood'. ${ }^{13}$ This line of criticism, however, is marginal in the text compared to the search for the reasons for the resentment of the Ukrainian peasantry.

\footnotetext{
${ }^{11}$ Odojewski, Zasypie wszystko, zawieje..., p. 199.

12 Odojewski, Zasypie wszystko, zawieje..., p. 296. The word 'czerń', which can be translated literally as 'blackness' has more connotations that the word 'mob', suggesting a dismissive and patronising attitude towards a poor, backward rural populace.

${ }^{13}$ Odojewski, Zasypie wszystko, zawieje ..., p. 296.
} 
In the above passages, Odojewski approaches questions to which contemporary historians still struggle to find answers. ${ }^{14}$ Yet commentators have criticises the author's tendency, in his considerations, towards the sentiment expressed by Teodor Czerestwieński that 'I keep thinking about it but I can't understand it', and a reversion to a fatalistic explanation for events. ${ }^{15}$ While Maria Janion sees Odojewski as consciously engaging with fatalism in a nod to the Romantic tradition, ${ }^{16}$ other critics see an abrogation of responsibility. Dorota Sapa argues that 'the enticing myth of the accursed Polish island puts to sleep the attentive mind seeking reasons for the hatred'. ${ }^{17}$ Ewa Wiegandt sees the presentation of social conflict through archetypes - especially through the biblical myth of Cain and Abel - as 'turning history into myth', thus avoiding complexity. ${ }^{18}$ For Edward Kasperski, Odojewski’s 'derivative post-Romantic symbolics [...] preclude any critical reflection - desirable in this instance - of the reasons for the tragedy being experienced' ${ }^{19}$ In Odojewski's moralising tale of martyrdom, the critic concludes, 'what remains beyond the field of vision is the most important reason for the tragedy: one's own blindness' ${ }^{20}$

The key element of Odojewski's 'blindness' is, undoubtedly, the lack of the Ukrainian perspective in his works. Ukrainians are present, but never as fully-formed characters. Even Gawryluk (almost always referred to by his surname), whose threatening presence saturates all three books, almost never speaks. Sapa argues in this regard that 'the

\footnotetext{
${ }^{14}$ See Grzegorz Motyka's explorations of the nature of the violence of the period in his Wolyn 1943 (Kraków: Wydanwnictwo literackie, 2016).

${ }^{15}$ See Edward Kasperski, 'Legitymizacja: najważniejszy problem powieści (o "epopee” W. Odojewskiego Zasypie wszystko, zawieje...) in Eugeniusz Czaplejewicz and Edward Kasperski, Literatura i różnorodność. Kresy i pogranicza (Warsaw: DiG, 1996), pp. 158-170.

${ }^{16}$ Janion, ‘Cierń i róża Ukrainy’, pp. 190-192.

${ }^{17}$ Sapa, Między polska wyspa a ukraińskim morzem, p. 168.

${ }^{18}$ Ewa Wiegandt 'Mit "tej ziemi”", in Stanisław Barć (ed.), Odojewski i krytycy. Antologia tekstów (Lublin: Wydawnictwo Uniwersytetu im. Marii Curie Skłodowskiej, 1999), pp. 201-210 (203).

${ }^{19}$ Kasperski, 'Legitymizacja', p. 166-167.

${ }^{20}$ Kasperski, 'Legitymizacja', p. 169.
} 
lack of a human voice from the Ukrainian side makes this side even more other, an even more impenetrable and unknown mass', ${ }^{21}$ while Kasperski puts it even more forcefully:

This 'other' is not only shown to be wrong in the novelistic discourse but does not even have the right to a voice, to motivations for his actions or to give his opinion on the opposing side that accuses him. He has no right to defence. He remains externally defined, judged without the right to appeal, morally executed. ${ }^{22}$

Elżbieta Dutka also notes the lack of Ukrainian voices, but argues that this is the result of the nature of a narrative so closely tied to certain characters:

In truth, we can speak only about our own convictions and opinions and can only imagine what the other side of a dialogue or conflict thinks. This is what the characters in the Podolian cycle do - they constantly try to access the reasons for the other side's actions, arguments. Hence the constant conjecture, agonising and agitation. $^{23}$

Certainly, Odojewski's prose is dominated by sprawling internal monologues and free indirect style, which could explain the lack of exploration of the psychological motivations of the Ukrainian characters. This initial choice, however, must also be the focus for interrogation in a text that examines a conflict with two sides, and in which one side is so frequently the focus of speculation.

The consequence of Odojewski's one-sided perspective is an image of Ukrainians as, as Sapa puts it:

[...] a collective deprived of all individuality, primitive and lacking willpower, a lazy mass $[l u d]$, singing songs and capable of the worst kind of barbarity. Knowledge of

\footnotetext{
${ }^{21}$ Sapa, Między polska wyspa a ukraińskim morzem, p. 220.

${ }^{22}$ Kasperski, 'Legitymizacja', p. 167.

${ }^{23}$ Elżbieta Dutka, Ukraina w twórczości Włodzimierza Odojewskiego i Włodzimierza Paźniewskiego (Katowice: Wydawnictwo Uniwersytetu Śląskiego, 2000), p. 36.
} 
the motivations for the actions of this mass is negligible. It does not go beyond the ambivalent image of the colourful village and the bloodthirsty mob. ${ }^{24}$

On the one hand, Sapa suggests, Ukrainians are 'invisible' or 'indiscernible'; on the other, , however, they are visible inasmuch as they add colour. Zmierzch świata, for example, begins with Piotr's childhood memories of the Ukrainian women who worked for his family:

Their high voices could often be heard in the kitchen (he loved to listen to them, hidden somewhere in the corner, so that he couldn't be seen), they sang or argued, and when they argued, their voices also sort of sang, and they weren't sad, although their voices were quite sad, and they sang in the garden, bent over or crouched down as the weeded the flowerbeds, and when there was nobody around they took him on their knees, hugged him and stroked him and he could remember that they had a powerful smell and big white teeth. ${ }^{25}$

References to Ukrainians, especially Ukrainian women, singing, or to their 'singing' voices and language are frequent. The Ukrainian language - or, at least, Odojewski's version of the dialect spoken in the region described - also appears frequently, with entire sentences untranslated. This, alongside similar though less frequent uses of German, Russian and Yiddish, may suggest a dialogic sensibility. Kasperski argues, however, that this, as well as the author's seemingly dialogic prose style, whereby characters' internal monologues are constantly inflected by other voices, merely creates an illusion of dialogue: the discourse of Polish martyrdom remains unchallenged, and these foreign elements act merely as 'decoration' in the arena of the exotic borderlands. ${ }^{26}$

One could go even further than Kasperski in this regard: foreign languages can in fact be appropriated to neutralise the potentially problematic voice of the other. In one scene,

\footnotetext{
${ }^{24}$ Sapa, Między polska wyspa a ukraińskim morzem, p. 208.

${ }^{25}$ Włodzimierz Odojewski, Zmierzch świata (Warsaw: Czytelnik, 1995), p. 6.

${ }^{26}$ Kasperski, 'Legitymizacja', p. 164.
} 
where Paweł fights with Polish partisans against Ukrainian nationalists, a local peasant stumbles onto the battle trying to find a doctor for his pregnant wife and is questioned by a Polish officer about his nationality (in the following, italics indicate where Odojewski uses transliterated Ukrainian):

'What are you, a Pole?', and the peasant [throughout the passage Odojewski uses the diminutive 'chłopek']: 'I don't know, kind sir, I'm looking for a doctor,' and Różkowski: 'Idiot! Pole or not?', and the peasant [...] in his lisping voice: 'What do you mean a Pole? What about that doctor?' and Różkowski: 'Ukrainian?', and the peasant, 'Devil take it, what Ukrainian, sir?' and Różkowski, taking his rifle off his shoulder: 'So what the hell are you then?', and the peasant: 'I'm local [miscewyj], sir, a Roman Catholic', now almost in tears $[\ldots]^{27}$

On the one hand, the passage highlights how national categories can be imposed on people with little concept of them. Yet there is a subtext: the peasant reveals himself not to be one of the enemy, with their fevered nationalism, but a 'good' local belonging to the old order, when the Polish landowners and the Ukrainian peasants lived in harmony. Nostalgia for the nonnationally-self-aware peasantry can also be seen in Wyspa ocalenia:

Who knows how many of the local villages support Gawryluk? Maybe a few, maybe all? The carriages that pass Ukrainian houses are no longer welcomed with a bow, a smile or a request to settle some family quarrel about land, or a request for advice about a sick relative. Silence has fallen. The black springs of poison that have pulsed under the surface ever since the times of the legendary Gonta [an $18^{\text {th }}$ century Cossack leader of uprisings against the Poles - UB] are now in full flow. ${ }^{28}$

\footnotetext{
${ }^{27}$ Odojewski, Zasypie wszystko, zawieje..., p. 320.

${ }^{28}$ Odojewski, Wyspa, p. 58.
} 
As the passages already cited demonstrate, Odojewski's image of Ukraine is defined by his use of references to 'mobs', 'bands', 'hordes', 'masses' who are variously 'wild', 'mindless' or 'bloodthirsty'. These overt references to an undifferentiated mass are accompanied by a subtler expression of imperceptibility that is built into the language used to describe individual Ukrainians. The indefinite adjective 'jakiś' (which has no direct equivalent in English but can be rendered as 'some', 'some kind of' or 'some... or other') is frequently used when referring to Ukrainians, particularly Ukrainian women:

My father had him [Gawryluk] with some local Ukrainian woman. ${ }^{29}$

Some Ruthenian cursed his horse loudly on the road. The throaty endings of the words merged into one, long singing sound. ${ }^{30}$

Some Ruthenian girl was walking down the side path carrying a bucket full of something. Her bare feet, which were covered in pine needles and the damp down of the willowherb that was flowering in the cuttings, were small, suntanned and covered in fresh scratches from the brambles. Katarzyna watched the girl as she disappeared around the corner, and thought about nothing. ${ }^{31}$

My father had him with some Ukrainian woman [dziewka ${ }^{32}$

[Piotr's] father had fathered both of them: Gawryluk with some Ukrainian woman and Piotr with his own wife. ${ }^{33}$

The use of 'jakiś' or 'jakaś' deprives the proceeding noun of specificity and individuality. Gawryluk's mother, the frequent object of this usage, is emblematic of Ukrainians more broadly: she is never named and no information is given about her.

\footnotetext{
${ }^{29}$ Odojewski, Zasypie wszystko, zawieje..., p. 11.

${ }^{30}$ Odojewski, Zasypie wszystko, zawieje..., p. 25.

${ }^{31}$ Odojewski, Zasypie wszystko, zawieje..., p. 63.

${ }^{32}$ Odojewski, Zasypie wszystko, zawieje..., p. 76.

${ }^{33}$ Odojewski, Zasypie wszystko, zawieje..., p. 179.
} 
Failure to perceive Ukrainians does not go unremarked in the novels, however, and is something of which the characters themselves display a degree of awareness. Here, Pawel reflects on his relationship with the local villagers:

When he looked at them, all those people seemed somehow [jacyś] warped, grotesque, deformed by work $[\ldots]$ almost dehumanized. $[\ldots]$ He tried to guess who among these people, who were an integral element of the surrounding landscape, connected to it by the eternal biological rhythm of tedious work [...] when dusk fell would take his sawn-off shotgun from behind a beam in the attic [...] and slip out into the dark, silent night $[\ldots]$ But he could not find an answer. In reality, he knew maybe a few, maybe a couple of dozen, but the rest remained for him, though he'd lived side by side with them since childhood, a nameless mass, without a face or internal life. Inscrutable and sullen. ${ }^{34}$

And later:

$[\ldots]$ this whole people $[l u d]$ from whose sweat the wealth of this land had grown, this people that was not perceived [nie dostrzegano], with whom nobody had reckoned, on whom backs had been turned, until it showed its back to its own motherland [macierza], this poor, dark, deceived people, stupefied in their humiliation $[\ldots]^{35}$ Here, Paweł's perception of the Ukrainians swings from a quasi-critique of his own ignorance to a characteristic reversion to citing the inscrutability of the other.

A similar dynamic can be observed in Piotr's attitude towards his half-brother in Wyspa ocalenia:

[...]. Actually, I don't know him at all, he thought, I don't know anything about him that might resemble the truth, these meetings seem as though they never happened,

\footnotetext{
${ }^{34}$ Odojewski, Zasypie wszystko, zawieje..., p. 104.

35 Odojewski, Zasypie wszystko, zawieje..., p. 124.
} 
they left little more than a vague impression on me of something that it's not possible to name. [...] and if he didn't know Gawryluk at all and had formed his opinion of him based on foggy, faded impressions and incomplete second-hand stories, then his judgement, his opinion, his view, these could not have any great value or sense. ${ }^{36}$ Piotr goes on to reflect that he may have underestimated the wrong done by his father to the boy and his mother, though he also sees it as an unremarkable and common situation in his society. He and other characters blame Gawryluk's resentment on a 'bastard complex, which has been given extra impetus by the coinciding national and class borders between his mother and father'. The nuances of the overlapping 'national' and 'class' borders are not explored in depth, however, and Piotr, echoing Teodor's 'mosaic' of reasons, concludes that 'this, and many other factors besides, could have constituted the force from which he drew his hatred' ${ }^{37}$ Like Paweł's, Piotr's reflections reveal a degree of awareness of his own limited perspective and of social complexities, but ultimately these lines of thought falter in the face of 'many other factors' and the fatalistic cycle of violence. In addition, with the speculative narrative of the 'bastard complex', Gawryluk's nationalism becomes a cover for private psychological motivations, undermining Gawryluk's political subjectivity (and, by extension, that of his fellow nationalists, and perhaps Ukrainians more broadly).

In all of the above, it is hard not to see echoes of colonial tropes and imagery, yet these are all but unnoticed in scholarship on Odojewski. The incomprehensible, wild 'natives', deprived of voice and subjectivity, resistant to the civilizing mission of the ruling elites, prone to wild outbursts of rage and easily manipulated - all this seems drawn from a checklist of colonial stereotypes. The threatening figure of Gawryluk, who is repeatedly shown observing the central characters from a distance, usually on horseback, recalls the

\footnotetext{
${ }^{36}$ Odojewski, Wyspa, p. 207.

${ }^{37}$ Odojewski, Wyspa, p. 209.
} 
native Americans in a Western watching the pioneers from a ridge. The resentment ascribed to him recalls that of the native who has one foot in the colonizer's world - the subaltern as famously described by Spivak, who, of course, cannot speak. And just as in Said's wellknown arguments, the image of the orientalised colonized subject is constructed not as a subject, but as a passive screen on which the colonized projects his own image. ${ }^{38}$

The colonial dimension of Odojewski's texts has a particularly important gendered aspect: as postcolonial gender theorists have shown, the bodies of women take on particular symbolic importance in the colonial encounter. While the central Polish female character, Katarzyna, is defined not just by her beauty, but also her social role and individual psychological nuances, the de-individualised Ukrainian women are defined by an earthy, sometimes animalistic physicality - as shown in the attention to the teeth or feet of the women in the citations above. Sexual dominance over 'native' women is symbolic of the emasculation of the colonized society, while the conquering of 'colonizing' women represents a symbolic breaking out of the marginal position of the colonized and occupation of the position of power of the colonizing male. ${ }^{39}$ As Inga Iwasiów has argued, the possession, punishment and rape of women is a key feature of the conflict represented in these texts: women become 'objects of exchange' and provide symbolic opportunities for male characters to transgress norms and exercise their subjectivity. ${ }^{40}$ Rape features frequently, and the threat of the kidnap and rape of Katarzyna by Gawryluk is one of the central factors driving the main characters' motivations. Gawryluk, in this sense, represents a classic case of colonial ressentiment as described by Fanon: rejected from the dominant

\footnotetext{
${ }^{38}$ See Gayatri Chakravorty Spivak, 'Can the Subaltern Speak,' in Cary Nelson and Lawrence Grossberg (eds), Marxism and the Interpretation of Culture (Urbana and Chicago: Illinois University Press, 1988), 271-313; Edward Said, Orientalism (New York: Random House, 1978).

${ }^{39}$ See Frantz Fanon, Black Skin, White Masks (London: Pluto Press, 2008), pp. 63-82; Homi Bhabha, The Location of Culture (London, New York: Routledge, 2004), p. 63; Sara Mills, Gender and Colonial Space (Manchester: Manchester University Press, 2005).

${ }^{40}$ Iwasiów, pp. 99-111
} 
culture, he wishes to both wreak revenge on his oppressors and occupy their position through possession of their women, through, as Piotr sees it, 'persistently hunting the women of our home'. ${ }^{41}$ Gawryluk, and his followers rape the Czerestwieńskis' servant girl, Julia, a Ukrainian who is considered part of their household, as punishment for being a 'pańska suka', or 'master's bitch', and tell her they would have killed her if she weren't of 'our faith' ${ }^{42} \mathrm{He}$ also rapes and murders the platonic love interest of Piotr's uncle Teodor, Irena. In an ultimate gesture of disdain and triumph, when he finally captures Katarzyna, he does not keep her, but gives her to a brothel for German soldiers.

In the end, the Ukrainian - whether the symbolic, de-individualized body of the Ukrainian woman or the primitive brute of the Ukrainian man - is little more than, in Pawel's words, an 'element of the surrounding landscape' - a detail in a Polish drama projected onto the neo-Romantic Ukrainian canvas. The Ukrainians who perpetrate violence are not political subjects, but blind instruments of fate as it submerges Poland in a recurring martyrological ritual. This is nowhere more clearly exemplified than in the final scene of Zasypie wszystko, zawieje..., when Paweł returns to his ruined home to retrieve the body of his mother, which the mob has thrown into a cesspit. The novel closes with Paweł dragging a block of ice containing the frozen body of his mother through the snow away from the ruined house. As he looks back, he sees two figures: the roadside figure of the Virgin Mary, and the the wife of a Ukrainian man who was among his mother's murderers, and whose house Paweł then burned down - with members of the family inside - in revenge. The image sums up the silent, symbolic, decorative nature of the Ukrainian in Odojewski's work: the Ukrainian is a silent witness in a Polish Romantic mystery play. The parallel between the women who

\footnotetext{
${ }^{41}$ Fanon, Black Skin, White Masks, p. 45; Odojewski, Zasypie wszystko, zawieje..., p. 363.

42 Odojewski, Wyspa, p. 133.
} 
witness Christ's crucifixion and the Ukrainian woman who witnesses the creation of the archRomantic image of Poland as the Christ of nations could hardly be clearer.

Odojewski's depiction of the Ukrainian, the significant other in Poland's encounters with its eastern borderlands, as lacking voice and subjectivity, speaks to an ongoing problem in Polish culture and society more broadly: the failure to find dialogue with the other. ${ }^{43}$ The implications of this kind of discourse are all the more important today, given the continuing deployment of antagonistic martyrological memory politics in relation to Ukraine by conservative Polish politicians and media, the ever-increasing numbers of Ukrainian migrants working in Poland, and the corresponding increase in anti-Ukrainian sentiment in Polish society. ${ }^{44}$ Odojewski’s texts represent both an exploration and exemplification of a certain kind of Polish 'blindness' to the Ukrainian other that can still be observed today. As outlined above, numerous critics have noted the author's failure to grapple with the thorny social, political and historical factors underlying the Volyn' massacres and Polish-Ukrainian relations more broadly, and it is hard to refute this; at the same time, if we want a nuanced exposé of the state of being trapped in colonial models of thinking and the inability to perceive the other and her subjectivity that this brings, Odojewski can act as a compelling, if not always necessarily self-conscious, guide.

\footnotetext{
${ }^{43}$ See Andrii Portnov, 'Clash of Victimhoods: The Volhynia massacre in Polish and Ukrainian memory', Open Democracy, 16 November 2016, https://www.opendemocracy.net/od-russia/andrii-portnov/clash-of-victimhood1943-volhynian-massacre-in-polish-and-ukrainian-culture

${ }^{44}$ See Paweł Smoleński, 'Ukraińcy się boją: W Przemyślu kibole dostali zielone światło. Wykrzykują: „Znajdzie się kij na banderowski ryj!”, Gazeta Wyborcza, 24 February 2018: 